Rupkatha Journal on Interdisciplinary Studies in Humanities (ISSN 0975-2935), Vol. 10, No. 1, 2018 Special Issue on "Interrogating Cultural Translation: Literature and Fine Arts in Translation and Adaptation" In collaboration with the Department of English, Amrita Vishwa Vidyapeetham Guest-edited by Dr. Hari M G, Amrita Vishwa Vidyapeetham, Coimbatore, India DOI: https://dx.doi.org/10.21659/rupkatha.v10n1.17

Full Text: http://rupkatha.com/V10/n1/v10n117.pdf

\title{
Violently Yours: Nation and its Other in Mohsin Hamid's The Reluctant Fundamentalist
}

\author{
Arnab Dasgupta ${ }^{1}$ \& Rupayan Mukherjee ${ }^{2}$ \\ ${ }^{1}$ Salesian College, Siliguri. \\ ${ }^{2}$ Department of English, University of North Bengal. Email: rupss.joy@gmail.com
}

Received October 31, 2017; Revised February 10, 2018; Accepted February 14, 2018; Published February 20, 2018.

\begin{abstract}
Nation States are constructed, imagined, represented and authenticated through the principle of inclusion and exclusion, where the idioms of culture, race, history, politics and ideology conjure what Anderson calls an "elastic space" beyond which lies the abyss of the other. The 'other' then becomes an essential component in discourses of Nation formation, as it is through a response to the other that the nation fashions its ontological identity, a "phenomenology of alterity". As Levinas points out in his essay "The Trace of the Other" : the outside of me solicits it in need: the outside of me is for me." The other is thus an intimate enemy for the nation. The nation is then latently reliant on the fixated identity of the other and is thus deeply apprehensive of this other and seeks an epistemic consummation of it in its totality. The nation state constantly interrogates the other: "what do you want from me?" which Zizek terms as "Che voi(?)" a constant interrogation which is the genesis of all forms of xenophobia. This in turn has the possibility to induce sporadic spectacles of active or passive violence through which the other responds to the nation. Such acts of violence then become an integral component of the performative of the other. In Mohsin Hamid's The Reluctant Fundamentalist, Chengiz Khan, a man who migrates to America, embracing the American dream, faces constant interrogation in a post 9/11 world from the host nation state to which he in turn responds through a form of passive violence, accomplishing the cult of the other. This paper interrogates into the performative of the other and the economy of violence which is inseparable from it and through a close analysis of the novel, explore the problematic relationship between the nation state and the other.
\end{abstract}

Keywords: Nation-State, Other, Ethics of Hospitality, Che vuoi, Big Other, Empirical Other, Ethnos, quilting, performative.

In your absence you polished me into the Enemy.

Your history gets in the way of my memory.

I am everything you lost. You can't forgive me.

I am everything you lost. Your perfect enemy."

Farewell.

Agha Shahid Ali

(C) AesthetixMS 2018. This Open Access article is published under a Creative Commons Attribution Non-Commercial 4.0 International License (http://creativecommons.org/licenses/by-nc/4.0/), which permits non-commercial re-use, distribution, and reproduction in any medium, provided the original work is properly cited. For citation use the DOI. For commercial re-use, please contact editor@rupkatha.com. 
Founded on the principles of exclusion and inclusion, States, in the words of Judith Butler "are certain loci of power" and signify "the legal and institutional structures that delimit a certain territory (Butler,2007 p. 03.)." As a part of its delimiting strategies, Nation state often devises the cult of the other. The Nation-State and its intimate 'other' are often engaged within the dialectics of difference and resemblance, "existing for each other, in relation to each other, in the exchange which separates them. (Foucault, 1988 p. 10) " The 'other' serving as a referential point, the Nation constantly fashions, re-fashions and identifies itself. This 'other', however isn't static and is often a historically contingent subject/object who is constantly remoulded, metamorphosed and mutated by the national imaginings. A few insightful examples will possibly illustrate the argument that we are trying to substantiate. The Medieval and Renaissance Europe's obsession with anti-semitism which reaches its zenith in the Auschwitz gas chambers of Nazi Germany, the racial apartheid of USA and South Africa or the xenophobic hostilities that diasporic migrants experience across the globe today are but a few examples of the diverse faces of the other. The Nation and its 'other' is thus engaged in what Levinas calls a "relation without relation." (Levinas, 1980 p. 52) This paper interrogates into the problematic relationship that the Nation shares with its 'other' and explores the familiarly unfamiliar position of the 'other' within and without the Nation State.

Nationalist discourse is functional within the performative trope of, what Butler calls "binding/unbinding". The grand narrative of nationalism that coercively binds the subjects to the homogeneous ideal of the Nation also accomplishes the act of unbinding, not only through expulsion, but also through imprisonment. The identity of the 'other' resides within this fissures of binding and unbinding and is neither assimilated nor expelled in totality from the Nationalist discourse. This 'other' resembles Derrida's notion of the foreigner which he explicates in his work Of Hospitality. The 'other' largely resembles Derrida's foreigner who "far from himself interrogating or appealing to the law and rights of the city, (he) is himself questioned, aphostrophised by the Laws."(Derrida, 2000 29) It is through an interrogation/interpellation of the 'Other' through the primordial question "What is your name?" that the Nation devises and extends its own "ethics of hospitality."

The National consciousness, to mitigate the anxiety caused by the rupture of the 'wholly other', attempts to reductively appropriate the Other. This appropriation superimposes what Benhabib calls ethnos (ethnos is a community of shared fate, memories and moral sympathies) over demos (a democratically enfranchised totality of all citizens who may or may not belong to same ethnos). This valorised superimposition conditions the ethics of unconditional hospitality and the pressing question is foregrounded, "can a Nation state be unconditionally hospitable to its other?" In her thoroughly researched work Islam, Migrancy and Hospitality Meyda Yegenoglu notes, "For Derrida, as an ethics, hospitality is infinite and unconditional. But if hospitality as ethics implies unconditionality and irreducibility to politics or legal regulation, how would it operate in a practical politics? (Yegenoglu, 2012 p.12)" Derrida points out in his work Of Hospitality that the idea of universal Hospitality is an impossibility and argues that "as though the law of hospitality defined this very impossibility, as if it were only possible to transgress it..." (Derrida, 2000 p.75).

Conditional Hospitality attempts an appropriation of the 'other' through continuous negotiations and compromises which are in coherence with and which simultaneously determine the ideology of the Nation state, a contingent process that Slavoj Zizek calls 
quilting. In his book titled The Sublime Object of Ideology, Zizek describes quilting as an appropriating event which "performs the totalisation by means of which (this) free floating of ideological elements is halted, fixed- that is to say, by means of which they become part of the structured network of meaning." (Zizek,1989 p.95) However, Zizek goes on to trace the element of excess that exceeds the appropriative measures of quilting and he argues that no ideological system can be absolutely totalitarian and there is always a possibility of the free floating signifiers to escape the sieve of ideology. It is in this element of excess that the empirical other escapes reductive strategies of appropriation and culminates into the 'big Other'(Zizek, 1989 p.103), an irreducible alterity which is beyond the symbolic order of language. The desire of appropriation of the 'other' by the self (in this case, the Nation) is breached by irreducible nature of the big 'Other'.

It is within the fissures of the appropriative quilt that the alterity of the big 'Other' is manifested, the fissures which are interruptive anxieties within the grand narrative of nationalism. It is in these moments of violence rupture that the big 'Other' surfaces as an archetype or to quote Jung a "primordial image", that had so long been an absent present within the collective unconscious of the 'ethnos'. While the empirical 'other' performs within the performative tropes of the ethnos, it is in these moments of rupture that the 'primordial image' of the big 'Other' transfixes itself on the empirical 'other'. The poetics of performativity which conceives the big 'Other' are ungoverned and hence incomprehensible for the Nation State, thus leading to a frantic interrogation by the Nation State, which Zizek calls "che vuoi?"(Zizek, 1989 p. 126) which translates into "what do you want from me?" Such a rhetorical question however has deeper implications as it not only attempts to interrogate into the 'other', but it is also a self introspection that calls into question the National subjectivity. It is with perplexity and dismay that the Nation interrogates itself: "Why am I what you (the big 'Other') are saying that I am?"(Zizek, 1989 p.126).

This completes the cycle of epistemic violence which is central to the lover's quarrel which the Nation and the 'other' are engaged in. The ethics of conditional hospitality which the Nation state extends to its 'other', the fictive ideal of the ethnos, the event of quilting are a few of the appropriative measures through which the Nation attempts to reduce and comprehend the empirical 'other'. It is however, in the moments of violent rupture that the measures of reduction and appropriation which the Nation state perpetuates on the empirical 'other' is interrupted, as the 'Big Other' uncannily surfaces and destabilises the authentic idea of the Nation state, promoting a violent self interrogation through which the Nation state attempts to decipher its own ontology.

Mohsin Hamid's celebrated novel The Reluctant Fundamentalist interrogates into the uncanny relation which the 'other' has with the Nation State. Changez, the protagonist is a Pakistani resident in USA, working for Underwood Samson and living an American dream until the catastrophe of 9-11, after which his relationship with the host Nation changes dramatically. Engaged in a conversation in a Lahore cafe with a nameless American stranger, Changez remonstrates his insecurities in a post 9-11 America as he reflects : “...I was aware of being under suspicion...”(Hamid,2007 p. 74) 9-11 affects Changez's private and public world and eventually Changez returns home, half willingly. Sporting a beard, Changez becomes a University lecturer with anti-imperialist affiliations, persuading his students "of the merits of participating in demonstrations for greater independence in Pakistan's domestic and international affairs, demonstrations that the foreign press would 
later, when our gatherings grew to newsworthy size, come to label anti-American." (Hamid, 2007 p.179).

As he sits at the Lahore cafe and narrates his 'substantial' experience at the United States, the anxiety between the 'other' and the Nation is foregrounded. His apparent attempts to nullify the angst through his benevolent declaration "Ah, I see I have alarmed you. Do not be frightened by my beard: I am a lover of America” (Hamid,2007 p. 01) becomes an ironic performance, both for the American stranger and for the readers. Changez's relationship with USA is the central theme of the novel and as the plot progresses through his narration, we decipher a significant shift in his estimation and hence his engagement with the host Nation.

In his own words, Changez was one among the handful number of international students who "were sourced from around the globe, shifted not only by well-honed standardized tests but by painstakingly customized evaluations-interviews, essays, recommendations."(Hamid, 2007 p. 04). A student at Princeton who was a recipient of financial aid, Changez soon realised that he had a role to play, he would have to actively contribute to the economy of the host Nation.

"In return, we were expected to contribute our talents to your society, the society we were joining."(Hamid, 2007 p. 04).

Within the economy of labour, the empirical 'other' would then get completely absorbed without resistance, a resonance of what Chomsky describes in his book Masters of Mankind as "consent without consent". Changez confesses:

"And for the most part, we were happy to do so. I certainly was, at least at first." (Hamid, 2007 p. 04).

Changez, pining with ambition, desires a job as a business valuation expert at Underwood Samson and Company, which would not only promise him a highly prospective career but more importantly, enable him to live the American dream. The empirical 'other', which in context of the novel is Changez, is thus quilted within the trope of the nationalist vision of USA- the American dream, a project which acknowledges the individual's role within the utilitarian idiom of profit. In other words, Changez is entrapped and appropriated through the capitalist ideology of work, that promises an upward mobility to the aspirant, irrespective of his/her 'ascribed status'.

The quilt of appropriation is however breached by the unconscious of the 'other', which is skilfully depicted in the novel through the tendentious joke which Changez pranks at his friends. Out on a picnic, Changez is asked by his fellow mate Chuck about his aspirations and he half-wittingly replies:

"I said I hoped one day to be the dictator of an Islamic republic with nuclear capability....."(Hamid,2007 p.29)

Sigmund Freud in his book Jokes and Their Relation to the Unconscious defines tendentious joke as that which contains lust, hostility or both. In Changez's case, it is through the device of humour that the cult of the 'big Other' surfaces, challenging the apparently stable quilt which the Nation weaves for its residents. Through the element of joke, the 'other' elocutes a rhetoric of violence which momentarily creates a state of paranoia within the ethnos. Simultaneously, the violence conveyed through humour negates 
the violence of appropriation which the all-engulfing homogeneous American dream had since then perpetuated.

Changez's tormented relationship with Erica is also deeply affected by his identity as the other. Being a Pakistani by descent, Changez realises his otherness which is manifested in his gaze at the woman's body.

"It is remarkable, I must say how being in Pakistan heightens one's sensitivity to a sight of a woman's body.... I had by the summer of my trip to Greece spent four years in America already-and had experienced all the intimacies college students commonly experience-but still I remained acutely aware of visible female skin."(Hamid, 2007 p.26)

His sensitivity to the female skin then becomes a behaviourial difference that he possesses owing to his non-American cultural disposition. Erica shows growing interest in Changez's cultural and national origin as she exoticises Pakistan and constantly interrogates him "So what's Pakistan like?"(Hamid,2007 p.27). In the 2012 cinematic adaptation of the novel which was directed by Mira Nayar, the exoticisation of Pakistan is overtly depicted by the photographic art exhibition that Erica organises playing around the cult of the 'other'. The photographs which depict Changez in his intensely personal moments not only appropriate him, but also violates his private space and integrity. Erica's seemingly innocent exhibition, which she claims symbolises her deep feelings for Changez, isn't free from the trope of epistemic violence that the West exercises on the non-Western by reduction, fixation and appropriation.

9-11 serves as an essential point of rupture within the plot of the novel, within Changez's psychic subjectivity and also in the homogeneous time of the Nation state. Changez, who had till then been inspired by the big American dream is rendered helpless by the untamed alterity that resists appropriation, a reality which Changez himself was unaware of. His first reaction to the catastrophe of 9-11 comes as a surprise, both to himself and the reader. "I stared as one-and then the other-of the twin towers of New York's World Trade Center collapsed. And then I smiled. Yes, despicable as it may sound, my initial reaction was to be remarkably pleased."(Hamid,2007 p.72). His rejoice at violence depicts the complete collapse of the performative which Changez had engaged in till then to live his life as an American.

It is in this world turned upside down that the Nation starts revising its policies to the other which in turn affects the ethics and conditions of hospitality and the performative of Nationalism is foregrounded. The heterotopic New York loses its tolerance to heterogeneity as Changez is stripped at the Airport owing to his ethnicity. A dismayed Changez observes the rising sense of Nationalism, bolstered by xenophobia in the ethnos. In a defamiliarised New York, Changez observes :

"Small flags stuck on toothpicks featured in the shrines; stickers of flags adorned windshields and windows; large flags fluttered from buildings. They all seemed to proclaim: We are America-not New York, which, in my opinion, means something quite different-the mightiest civilisation the world has ever known; you have slighted us; beware our wrath. Gazing up at the soaring towers of the city, I wondered what manner of host would sally forth from so grand a castle." (Hamid, 2007 p. 79). 
As the hostility of the Nation state to its 'other' intensifies, Changez is sent to Chile, where through his interactions with Juan-Bautista, Changez grows conscious of his function as a modern day janissary in the capitalist market economy of USA. Janissaries, who were conscripted young Christian boys, made up the first standing army of the Ottoman Empire and were often used to combat Christian territories. Changez, as the perpetual 'other', soon discovers his role as the modern day janissary serving the imperialistic motives of America, so consumed by the big American dream that he had till then overlooked the impending threat of war that the US was posing against Islamic states like Pakistan.

Through his epiphanies, Changez becomes conscious of his permanence as an immutable 'other', which till then had been concealed beyond the veils of liberal economic ideologies. It is from this point that he creeps into the performative of the 'big Other' who violates the constructed homogeneity of the ethnos, and consequently makes a violent departure. The ontological shift in Changez, his departure from being a janissary intoxicated by the big American dream to his persona of a labelled anti-American exemplify the two diverse yet related performatives, the performative of the 'empirical other' and the performative of the big 'Other'.

It is crucial to understand that the Nation too shares a close nexus with the trope of the performative, as is depicted in the novel. Post 9-11, the celebration of Americanism and the gestures of violence which the American state depicts to its Islamic other are instances of the Nation performing its own conceived identity. In his book The Location of Culture, Homi Bhabha argues that the element of cultural identification which creates grand narrative of National consciousness is formulated through the trope of performative. The principles of the performative of national consciousness demands the counterperformative of the 'big Other'. The Nation and its 'other' are located within two contrary yet referential set of performatives which constantly interrogate into one another through the rhetoric of hospitality and 'Che vuoi?'. The constant friction between the two removed yet referential performatives creates ruptures within the quilt of Nationalism through which sporadic forms of violence emerge.

The Nation and its 'other', as we have tried to substantiate, are engaged in a relationship which is scarred with both latent and active forms of violence. Violence becomes the only possible rhetoric through which the Nation and its 'other' engages in a communication of performativity, one that constructs and sustains both. As Partho Chatterjee observes in Nationalist Thought and the Colonial World: A Derivative Discourse:

"Nationalism..........seeks to represent itself in the image of the Enlightenment and fails to do so. For Enlightenment itself, to assert its sovereignty as the universal ideal, needs its Other; if it could ever actualise itself in the real world as the truly universal, it would in fact destroy itself."(Chatterjee,1986 p. 17) 


\section{References:}

Butler, Judith, and Gayatri Chakravorty Spivak. (2007). "Who Sings the Nation State?:languages, politics, belonging. New York: Seagull Books.

Foucault, Mitchel. (1988). Madness and Civilization:A History of Insanity in the Age of Reason. New York:Vintage.

Levinas, Immanuel. (1980). Totality and Infinity.London:Martinus Nijhoff Publishers and Duquesne University Press.

Derrida, Jacques. (2000). Of Hospitality. Paris: Stanford University Press.

Yegenoglu, Meyda.(2012). Islam, Migrancy and Hospitality in Europe. New York : Palgrave Macmillan.

Zizek, Slavoj. (1989).The Sublime Object of Ideology. London: Verso Press.

Hamid, Mohsin. (2007).The Reluctant Fundamentalist. New Delhi:Penguin Books.

Chatterjee, Partho. (1986). Nationalist Thought and the Colonial World: A Derivative Discourse. London: Zed.

Arnab Dasgupta is an assistant professor at Salesian College, Siliguri and is currently pursuing his Mphil. at the Department of English, University of North Bengal. His areas of interest include Postcolonial Fiction, Postmodernism and Indian writing in English.

Rupayan Mukherjee is currently pursuing his Phd. at the Department of English, University of North Bengal. He is also employed as a Guest lecturer at the University B.T. and Evening College, Cooch Behar. His areas of interest include Modernism, South Asian Fiction and Other literatures. 